indirectly responsible for a museum or art gallery is neglecting an essential part of his duty if he is not taking all feasible steps to protect his collections from possible war risks.

A discussion on museums and field archæology, opened by Sir Cyril Fox, director of the National Museum of Wales, led to a general agreement that field work is a most important part of the training of museum officials who are in charge of archrological material. Not only does it enrich the museum, but it also provides officials with personal contacts, and a background of knowledge that is invaluable in the study of their own collections. Curators should be given facilities to take part in excavations as an official part of their museum work. In the same discussion, Mr. Christopher Hawkes of the British Museum directed attention to the need for a national archæological survey with centralized records.

"Youth in Museums" was a subject of three papers by Miss Mary S. Shaw, Miss C. Mirèio Legge and Miss Bertha Hindshaw, all of Manchester, who, from the point of view of an Egyptologist, a zoologist and the curator of a children's museum, discussed the way in which museum collections could be used for vivid educational work.

Mr. Trevor Thomas, of the Liverpool Public Museums, read an original and stimulating paper on the æsthetics and technique of museum display-a subject which is, perhaps, of little obvious concern to the scientific worker, but which is, nevertheless, of the very greatest importance if museum exhibits are to appeal to the visitor, whose attention is arrested by vigorous display, in which the objects are grouped and arranged in an attractive manner. In this connexion, the results of experimental psychology should not be neglected.

Mr. Frank Pick, of the London Passenger Transport Board, gave a vigorous address on the form and purpose of a local museum, which was illustrated by many comparisons between museums in Britain and those in other countries. The primary question is, he said, to whom or to what is a museum directed ? It is necessary for every museum to work to a specific aim and purpose, and specialized museums are needed; for example, Britain has no museum giving a synopsis of the history and development of agriculture, nor is there one dealing with the history, meaning and purpose of clothes. A museum can justify itself only as it establishes relationships with current life, and its administration is work requiring great imaginative activity.

Among other papers at the Conference, Mr. E. Rimbault Dibdin discussed the question "Are Art Galleries Obsolete ?" ; Mr. J. H. Hewitt talked of the place of reproductions in the gallery; $\mathbf{M r}$. A. F. Reeve Fowkes made a plea for a circulating national gallery, and Mr. J. A. S. Stendall described museum methods in Scandinavia. A film on the work of the Royal Scottish Museum was presented by its director, Mr. T. Rowatt.

Mr. S. F. Markham, discussing the future of the museum movement in Britain, made an informative and practical contribution. His views will no doubt be found expressed in detail in the report on this subject which he is preparing for the Carnegie United Kingdom Trustees.

About two hundred and thirty delegates attended the Conference, and were entertained by the Lord Mayor of Belfast, by the Belfast Museum Committee, and by Queen's University. There were excursions to the Giant's Causeway, to Armagh, and to archæological sites in Northern Ireland.

Next year's Conference will be held at Cheltenham in the week commencing July 3; it will be the jubilee of the Museums Association, and will be under the presidency of Viscount Bledisloe.

\title{
International Physiological Congresses
}

$\mathrm{T}$ HE sixteenth International Physiological Congress, which will be held in Zurich on August 14-19, may be considered to mark the fiftieth anniversary of the first congress, which was held in the same country. In honour of the occasion, F. J. Franklin has written a fascinating history of these congresses, which is published in Annals of Science (3, Part 3). It is illustrated with thirty-five photographs of presidents of the congresses and others who have contributed to their success. Copies are to be presented to all members.

Dr. Franklin gives a large number of details of the organization of these congresses which will be very useful to those responsible for congresses in the future, but he has done far more than this. He has managed to catch and convey something of the enthusiastic spirit which animated the early congresses, when about a hundred keen workers met together to demonstrate experiments to one another. Every effort was made to keep the arrangements as simple as possible, and particular stress was laid on the importance of demonstrations. There was at one time a movement in favour of abolishing other forms of communication altogether, but this was thought to be impracticable.
The first congress was the result of a letter sent by the Physiological Society, London, to 109 physiologists in 1888. It met the next year in Basle, and Dr. Franklin quotes interesting reminiscences of several of the eleven survivors. This congress was so successful that it was decided to hold similar congresses every three years, and they met successively at Liége, Bern, Cambridge, Turin, Brussels, Heidelberg, Vienna and Groningen (1913). Speeches were made which emphasized the international spirit of science, and it is sad to remember how this spirit was forgotten in the years of the Great War. The congress in Paris in 1920 was confined to physiologists from allied countries, and the next truly international congress was held in Edinburgh three years later. Since then congresses have been held in Stockholm, Boston, Rome and Leningrad. The membership has grown to about 1,500 and the scientific demonstrations have tended to be overshadowed by the banquets, concerts and sight-seeing expeditions which have been generously provided by the Governments of some of the countries which have acted as hosts.

An attempt is being made this year to return to the simplicity of the early congresses. Membership 
is limited to genuine physiologists and their families, and the social entertainments will be less elaborate, but physiology itself cannot be made simple again. The number of communications is large, and it is still necessary to hold meetings simultaneously in five lecture rooms.

The Swiss organizing committee is introducing important innovations. Fifteen discussions have been organized on the kidney, the regulation of the circulation, the chemical transmission of nervous impulses, oxidation, the permeability of the skin, electro-physiology, steroids, fotal respiration, nutri- tion, the control of respiration, the adrenal cortex, the anterior pituitary, the analysis of speech, the potential action of drugs and vitamin $B_{2}$. The contributions of the two openers of each of these discussions have already been circulated with the general programme of the meeting. The opportunity to study such documents in advance is a great boon, but it has only been granted once before. There is every reason to hope that this congress will be remembered for the high value of its scientific meetings.

\section{J. H. Gaddum.}

\section{Beit Memorial Fellowships for Medical Research}

$\mathrm{A}^{\mathrm{T}}$ T a meeting of the trustees of the Beit Memorial Fellowships for Medical Research held on July 13, it was reported that F. R. Winton (fellow, 1927-31) had been appointed to the professorship in pharmacology in the University of London, held at University College ; G. R. Cameron (fellow, 1930-33) to the professorship of morbid anatomy in the University of London, held at University College Hospital Medical School; A. R. Todd (fellow, 1935-36) to the professorship of chemistry in the University of Manchester ; and that R. J. Kellar (fellow, 1935-37) had been appointed reader in obstetrics and gynæcology, University of London, at the British Postgraduate Medical School, London.

The total number of fellowships held by full-time workers during the year $1937-38$ was 23 . The number of candidates at the present election was higher than usual ; five applied from Canada and three from Australia. Fortunately, reserve funds made it possible to award more junior fellowships than are ordinarily given each year, and the election of twelve new junior fellows brought the total of those elected since the beginning of the Trust in 1910 to be exactly 200. A fresh edition has been printed this year of the "Green Book" which summarizes briefly the after-careers of fellows and their present position in research.

The following elections were made, the subject and place of research being given after each name :

Senior Fellowship (value $£ 700$ a year) : Dr. D. E. Green, to continue research on the role of vitamin $B_{1}$ in the oxidation of pyruvic acid, and to study a new flavin-protein compound in milk (Institute of Biochemistry, University of Cambridge).

Fourth Year Fellowship (value $£ 500$ a year): Dr. M. H. Salaman, to continue research on vaccinia and animal pox viruses (Lister Institute of Preventive Medicine, London).

Junior Fellowships (normal value $£ 400$ a year): Dr. G. Bourne, director of the Department of Experimental Biology, Australian Institute of Anatomy, Canberra, 1935-36 and biochemist, Commonwealth Advisory Council on Nutrition, 1937-significance of vitamin $\mathbf{C}$ in the endocrine system (Department of Human Anatomy, University of Oxford); Dr. A. L. Chute, of Toronto General Hospital-experimental studies in metabolism of the brain (Department of Physiology, University College, London); Dr. R. O. L. Curry-physiology of speech disorders by photographic study of laryngeal movements
(University College, London); Dr. J. F. Danielli, demonstrator in biochemistry and biophysics, University College, London-permeability of normal and denervated muscle to metabolic products and to drugs (Institute of Biochemistry, University of Cambridge) ; Dr. J. G. Dewan, assistant physician, Toronto Psychiatric Hospital, 1933-35, and since 1936 research worker at the Institute of Biochemistry, Cambridge- 'insulin shock' treatment of schizophrenia by experimental studies of brain metabolism (Institute of Biochemistry, University of Cambridge) ; Dr. Catherine O. Hebb, since 1937 research assistant, Department of Physiology, McGill Universityeffect of thoracic sympathectomy on the activities of the lung (Department of Physiology, University of Edinburgh); Dr. B. Katz, since 1935 research worker in biophysics, University College, Londonelectric excitation and transmission of impulses in nerve and muscle of animals (Department of Biophysics, University College, London) ; J.H. Kellgren, resident appointment, University College Hospital, London, 1935-36, and since 1937 research worker in its Department of Clinical Research-painful conditions of the limbs and back (Department of Clinical Research, University College Hospital, University of London; Dr. J. J. D. King, house surgeon, Dundee Dental Hospital 1931-32, since 1936 research grantee of Medical Research Council-dental caries and parodontal disease (Medical School, University of Sheffield); Dr. H. Lehmann, research worker, Physiological Institute, Heidelberg, 1934-36, since 1936 research student of Christ's College, Cambridge -blood sugar in animals, and iron metabolism in plants (Institute of Biochemistry, University of Cambridge); W. J. O'Connor, resident medical officer, Adelaide Hospital, 1936, lecturer in human physiology and pharmacology, University of Adelaide, 1936-37-effect of strophanthin on the oxygen consumption of the heart (Laboratory of Pharma. cology, University of Cambridge); H. Scarborough, house physician, Royal Infirmary, Edinburgh, since 1934 assistant in Department of Therapeutics, University of Edinburgh-mode of destruction of vitamin $\mathbf{C}$ in the human body (Clinical and Chemical Laboratories, Royal Infirmary, Edinburgh).

All correspondence of fellows and candidates should be addressed to Prof. T. R. Elliott, honorary secretary, Beit Memorial Fellowships, University College Hospital Medical School, University Street, London, W.C.1. 